\title{
Abstract withdrawn by the author
}

From 16th Annual SCMR Scientific Sessions

San Francisco, CA, USA. 31 January - 3 February 2013

\section{Abstract withdrawn by the author}

Published: 30 January 2013

doi:10.1186/1532-429X-15-S1-P130

Cite this article as: : Abstract withdrawn by the author. Journal of

Cardiovascular Magnetic Resonance 2013 15(Suppl 1):P130.

Submit your next manuscript to BioMed Central and take full advantage of:

- Convenient online submission

- Thorough peer review

- No space constraints or color figure charges

- Immediate publication on acceptance

- Inclusion in PubMed, CAS, Scopus and Google Scholar

- Research which is freely available for redistribution

Submit your manuscript at www.biomedcentral.com/submit

\section{() Biomed Central}

